Sección Básica / Basic

Artículos de investigación / Research paper

\title{
Arthropods associated with Callisthene fasciculata (Vochysiaceae) canopy in the Pantanal of Mato Grosso, Brazil
}

\author{
Artrópodos asociados a copas de Callisthene fasciculata (Vochysiaceae) \\ en el Pantanal de Mato Grosso, Brasil \\ LÚCIA YAMAZAKI'; VANESSA FRANÇA VINDICA²; MARINÊZ ISAAC MARQUES; \\ LEANDRO DENIS BATTIROLA ${ }^{4}$
}

\begin{abstract}
${ }^{1}$ M. Sc. Universidade Federal de Mato Grosso. Av. Alexandre Ferronato 1.200, CEP 78557-267, Sinop, Mato Grosso, Brazil, lucia_yamazaki_ly@hotmail.com, https://orcid.org/0000-0003-0734-5485. ${ }^{2}$ M. Sc. Universidade Federal de Mato Grosso, Av. Alexandre Ferronato 1.200, CEP 78557-267, Sinop, Mato Grosso, Brazil, v.francavindica@yahoo.com.br, https://orcid.org/0000-0002-2633-2658. ${ }^{3}$ Ph. D. Universidade Federal de Mato Grosso, Av. Fernando Corrêa da Costa, s/n, CEP 78060-900, Cuiabá, Mato Grosso, Brazil, marinez513@gmail.com, https://orcid.org/0000-0002-9890-8505. ${ }^{4}$ Ph. D. Universidade Federal de Mato Grosso, Av. Alexandre Ferronato 1.200, CEP 78557-267, Sinop, Mato Grosso, Brazil, ldbattirola@uol.com.br, https://orcid.org/0000-0002-5920-5997.
\end{abstract}

Corresponding author: Lúcia Yamazaki. M. Sc. Universidade Federal de Mato Grosso, Av. Alexandre Ferronato 1.200, CEP 78557-267, Sinop, Mato Grosso, Brazil, lucia yamazaki ly@hotmail.com, https://orcid.org/0000-00030734-5485.

Suggested citation:

YAMAZAKI, L.; VINDICA, V. F.; MARQUES, M. I.; BATTIROLA, L. D. 2020. Arthropods associated with Callisthene fasciculata (Vochysiaceae) canopy in the Pantanal of Mato Grosso, Brazil. Revista Colombiana de Entomología 46 (1): e10168. https://doi. org/10.25100/socolen.v46i1.10168

Received: 11-Mar-2017

Accepted: 24-Nov-2019

Published: 20-Aug-2020

Revista Colombiana de Entomología

ISSN (Impreso): 0120-0488

ISSN (En línea): 2665-4385

https://revistacolombianaentomologia.univalle.edu.co/

Open access

Publicadores / Publishers:

Sociedad Colombiana de Entomología SOCOLEN (Bogotá, D. C., Colombia) http://www.socolen.org.co Universidad del Valle (Cali, Colombia) http://www.univalle.edu.co/

(C) 2020 Sociedad Colombiana de Entomología - SOCOLEN y Universidad del Valle - Univalle
Abstract: Studies on arthropods associated with tropical rainforest canopies contribute to a further understanding of forest canopy community dynamics and their relationship to the structure and function of this ecosystem. This study evaluated arthropod community composition in monodominant Callisthene fasciculata forest canopy throughout the high water and dry periods in the northern region of the Pantanal in Mato Grosso, Brazil, as a part of a project about arboreal canopy arthropods associated with monodominant areas in this region. Sampling was conducted on 12 individuals of $C$. fasciculata, six from the high water season (2010) and six from the dry season (2011), using insecticide fogging. A total of 28,197 arthropods were collected. Hymenoptera (the majority being Formicidae), Diptera, Acari, Thysanoptera, Hemiptera and Coleoptera, were the most representative groups. Although the analysis did not show variation in the abundance of individuals between the high water and dry seasons, the arthropod community varied significantly in taxa composition. Opiliones, Embioptera, Ephemeroptera and Scorpiones occurred only during the high water period, with Polyxenida and Strepsiptera occurring only in the dry season. Thysanoptera was more abundant in the dry season, showing a relationship with the beginning of the $C$. fasciculata flowering period. In general, the high water and dry seasons maintain distinct communities in this habitat, illustrating how the temporal variation in the phenology of C. fasciculata imposed by the Pantanal's hydrological regime alters the composition of the associated arthropod communities in the canopy of these monodominant formations in the Pantanal of Mato Grosso.

Keywords: Biodiversity, Callisthene fasciculata, communities, phenology, thermonebulisation, wetlands.

Resumen: Los estudios sobre artrópodos asociados a las copas de árboles en bosques tropicales contribuyen a comprender la dinámica de comunidades de dosel y su relación con la estructura y función de este importante ecosistema. Este estudio evaluó la composición de la comunidad de artrópodos en copas de árboles de Callisthene fasciculata en bosques monodominantes de esta especie, a lo largo de dos períodos estacionales, inundación y sequía, en la región norte del Pantanal de Mato Grosso, Brasil, como parte de un proyecto sobre artrópodos del dosel en bosques monodominantes en esta región. Los muestreos fueron realizados en 12 individuos de C. fasciculata, seis en periodo de inundación (2010) y seis en época seca (2011), aplicando el método de termonebulización de copas con insecticida. Un total de 28.197 artrópodos fue recolectado. Hymenoptera (Formicidae, en su mayoría), Diptera, Acari, Thysanoptera, Hemiptera y Coleoptera fueron los grupos más representativos. A pesar que los análisis no demostraron variación en la abundancia de individuos entre los períodos de inundación y sequía; la comunidad de artrópodos varió significativamente en función de la distribución de los taxones que la componen. Los opiliones y escorpiones se registraron únicamente durante el período de inundación, mientras que Polyxenida y Strepsiptera solo durante el periodo seco. Thysanoptera fue el orden más abundante en la época seca, lo que evidencia la relación con el inicio del periodo de floración de C. fasciculata. En general, durante los periodos estacionales de sequía e inundación estos árboles mantienen comunidades distintas de artrópodos. La variación temporal impuesta por el régimen hídrico del Pantanal afecta la fenología de las especies vegetales como $C$. fasciculata lo que altera, consecuentemente, la composición de las comunidades de artrópodos asociadas al dosel de estas manchas monodominantes en el Pantanal de Mato Grosso.

Palabras clave: Biodiversidad, Callisthene fasciculata, comunidades, fenología, termonebulización, humedales. 


\section{Introduction}

Treetops are defined by the aggregation of leaves, branches and their offshoots, as well as the interstices of air in a forest canopy (Nadkarni 1994; Moffett 2000), which makes this environment extremely diverse and of considerable importance for the maintenance of forests in regards to both nutrient cycling processes and the ecological interactions between the species inhabiting them (Adis 1997; Adis et al. 2010). Studies on arthropods associated with forest canopy in wetlands have revealed, besides high species diversity, the effects that seasonal abiotic variations have on the structure of their assemblages (Battirola et al. 2014, 2016; Yamazaki et al. 2016, 2017).

Recent studies have examined the assemblages of different groups of arthropods in the canopies of distinct phytophysiognomic formations in the Pantanal of Mato Grosso, such as monodominant formations of Attalea phalerata Mart. (Arecaceae) (Santos et al. 2003; Battirola et al. 2004, 2005, 2007, 2014, 2017b), Vochysia divergens Pohl. (Vochysiaceae) (Marques et al. 2001, 2006, 2014, Battirola et al. 2016, 2017a), and Calophyllum brasiliense Cambess. (Guttiferae) (Marques et al. 2007). Another important monodominant formation in the northern Pantanal region is formed by Callisthene fasciculata (Spr.) Mart. (Vochysiaceae), object of this work.

Previous results specific to some arthropod groups associated with $C$. fasciculata have already been published as ants (Yamazaki et al. 2016) and spiders (Yamazaki et al. 2017), considering the specific and in-depth discussions that each taxonomic group needs. This tree species, in the monodominant densities found in this region of the Pantanal, was also mentioned as a refuge for Scorpions during seasonal floods (Yamazaki et al. 2015). Local differences in the intensity and duration of floods associated with Pantanal topographic variations shape the landscape and consequently the distribution of different vegetation formations, thus creating a habitat mosaic of monodominant forests, influencing the biodiversity associated with this areas (Arieira and Nunes-da-Cunha 2006; Junk et al. 2006; Nunesda-Cunha and Junk 2011, 2015). The temporal variation of the water level in wetlands such as the Pantanal makes flooding a determining factor in its ecological processes (Junk 1993; Junk et al. 2015).

Considering the importance of the knowledge of arthropod diversity for the maintenance of ecological dynamics and conservation of wetlands, as well as the role played by arthropods in communities associated with the forest canopy (e.g. Yamazaki et al. 2016, 2017), this study evaluated the composition of the arthropod community associated with monodominant Callisthene fasciculata forest canopy and variations between the high water and dry seasons within the northern Pantanal region of Mato Grosso, Brazil, and aims to increase knowledge in relation to Pantanal biodiversity.

\section{Materials and methods}

Study area. Sampling was conducted within a monodominant, seasonally flooded forest with predominance of $C$. fasciculata during the high water (2010) and dry (2011) seasons of the northern Pantanal on the Porto Cercado road, specifically, on the Alvorada farm (16 $\left.26^{\circ} 846^{\prime \prime} \mathrm{S}, 56^{\circ} 24^{\prime} 951^{\prime \prime} \mathrm{W}\right)$, Poconé, Mato Grosso, Brazil. The region is characterized by dry winters and wet summers, with temperatures ranging between $22{ }^{\circ} \mathrm{C}$ and $32{ }^{\circ} \mathrm{C}$ (Hasenack et al. 2003). The local climate is tropical savannah, type AW under the Köppen classification system (e.g. Yamazaki et al. 2016; 2017). Annual rainfall varies between 1,000 and $1,500 \mathrm{~mm}$, with periods of rainfall below $10 \mathrm{~mm}$ occurring over several months (Radambrasil 1982). Heckman (1998) affirm that this region has well defined seasons, with a wet period between October and March, and a dry period between April and September, resulting in a hydrological cycle of four distinct seasonal periods (high water, receding water, dry season and rising water) (e.g. Wantzen et al. 2016).

Callisthene fasciculata is characterized as deciduous with no expiration from the rising water period to the beginning of the dry period, partial expiration from the dry period to the beginning of the rising water period and total expiration at the end of the dry season (Corsini and Guarim-Neto 2000). The trees that reach between 4 (four) to 15 (fifteen) $\mathrm{m}$ in height, have a dark, thick and very rough bark (Pott and Pott 1994). The flowering period occurs between September and October together with the dispersion of seeds generated in the previous year (Custódio et al. 2014).

Methods. Canopy fogging was conducted in a total of twelve C. fasciculata canopies - six during high water season/2010 and six in the dry season/2011 as described in Yamazaki et al. $(2016,2017)$. The trees were randomly selected, maintaining a minimum distance of $10 \mathrm{~m}$ between each specimen according to the criteria proposed by Adis et al. (1998), and the methodological procedures of Battirola et al. (2004). The entire diameter at the base of the trees was surrounded by nylon funnels (area of $1 \mathrm{~m}^{2}$ each) distributed according to the reach/range and architecture of the canopy, totaling $120 \mathrm{~m}^{2}$ of sampled area $\left(10 \mathrm{~m}^{2}\right.$ per sampled tree $)$. The base of each collecting funnel contained $92 \%$ alcohol in a plastic collecting vial, which was suspended $1 \mathrm{~m}$ from the ground by ropes tied to neighbouring trees. During the high water period funnels were suspended $1.5 \mathrm{~m}$ from the ground due to raised water levels within the forest (water depth ranged from 0.1 to $0.3 \mathrm{~m})$.

The methodological procedures were the same as those described by Yamazaki et al. $(2016,2017)$. Canopy fogging was carried out for a duration of ten minutes on each sample tree, using $0.5 \%$ Lambdacialotrin $\left(\operatorname{Icon}^{\circledR}\right.$ ) synthetic pyrethroid, diluted in two litres of diesel oil at a concentration of $1 \%(20 \mathrm{ml})$, combined with Synergist (DDVP) $0.1 \%$ (2 ml) (Yamazaki et al. 2016, 2017). The thermo-nebuliser used was Swingfog SN50, which produces a strong jet that is directed from the ground to all parts of the canopy. These procedures always occurred at approximately 06:00 am, when air circulation is less intense, allowing the insecticide cloud to rise slowly through the canopy without dispersing (Adis et al. 1998, Battirola et al. 2004). Collections were carried out two hours after insecticide application (fogging) of each sampled tree, which is the recommended time frame for this action (Adis et al. 1998). Following this procedure, the funnel walls were manually shaken and washed with a spray containing 92 $\%$ alcohol, and the material packed in collection flasks located at the funnel bases. The collected arthropods were transported to the Acervo Biológico da Amazônia Meridional (ABAM) at the Universidade Federal de Mato Grosso, Sinop-MT, Brazil, to be screened, quantified and identified at the level of order and/or suborder according to Rafael (2012). The testimonial 
material was deposited in the Entomological Collection of ABAM.

Data analysis. A $t$-test was used to evaluate any variation in abundance of the arthropod community between the high water and dry seasons. The distribution of taxonomic arthropods orders was evaluated using indirect ordination by Non-Metric Multidimensional Scaling (NMDS), using the first ordination axis, based on quantitative data and BrayCurtis similarity measure. Data normality was validated by Shapiro-Wilk. All analyses were performed using R software, version 3.0.1 (R Core Team 2013), and the Vegan package (Oksanen et al. 2013).

\section{Results}

As a result of the collections undertaken in the Pantanal of Mato Grosso during the high water and dry seasons, 28,197 arthropods were collected from $C$. fasciculata canopies, with a density of 235.0 ind.$/ \mathrm{m}^{2}$, represented by Hexapoda $(21,872$ ind.; $77.6 \%$; 182.3 ind. $/ \mathrm{m}^{2}$ ), Arachnida (6,313 ind.; $22.4 \%$; 52.6 ind. $/ \mathrm{m}^{2}$ ) and Diplopoda (12 ind.; <0.1\%, 0.1 ind. $/ \mathrm{m}^{2}$ ) . Individuals were distributed in 24 orders (Table 1) of which Hymenoptera, Diptera, Acari, Thysanoptera, Hemiptera and Coleoptera were predominant (Fig. 1).

Hexapoda was the most abundant group with 18 orders. Hymenoptera (6,635 ind.; $23.5 \%$; 55.3 ind. $\left./ \mathrm{m}^{2}\right)$, with the majority being Formicidae (2,958 ind; $44.6 \%$ of Hymenoptera; 24.7 ind./ $/ \mathrm{m}^{2}$ ), Diptera (5,105 ind.; $18.1 \%$; 42.5 ind. $\left./ \mathrm{m}^{2}\right)$ and Thysanoptera (4,335 ind.; $15.4 \% ; 36.1$ ind./ $\mathrm{m}^{2}$ ) were the most represented taxa, followed by Hemiptera, including Heteroptera, Auchenorrhyncha and Sternorrhyncha $\left(2,391\right.$ ind.; $8.5 \% ; 19.9$ ind.$\left./ \mathrm{m}^{2}\right)$ and Coleoptera (1,663 ind.; 5.9 $\%$; 13.9 ind.$/ \mathrm{m}^{2}$ ). Dermaptera, Embioptera, Ephemeroptera, Isoptera, Mantodea, Neuroptera, Orthoptera, Strepsiptera and Trichoptera, with 185 individuals (1.3\% of the total; 3.1 ind./ $\mathrm{m}^{2}$ ), were the least abundant groups (Table 1). Arachnida was represented by five orders with predominance of Acari $(4,642$ ind.; $16.5 \% ; 38.7$ ind. $/ \mathrm{m}^{2}$ ) and Araneae (1,610 ind.; $5.7 \%$; 13.4 ind. $\left./ \mathrm{m}^{2}\right)$, while Opilions, Pseudoscorpions and Scorpions totalled just 61 individuals $\left(0.2 \% ; 0.5\right.$ ind. $\left./ \mathrm{m}^{2}\right)$. Only 12

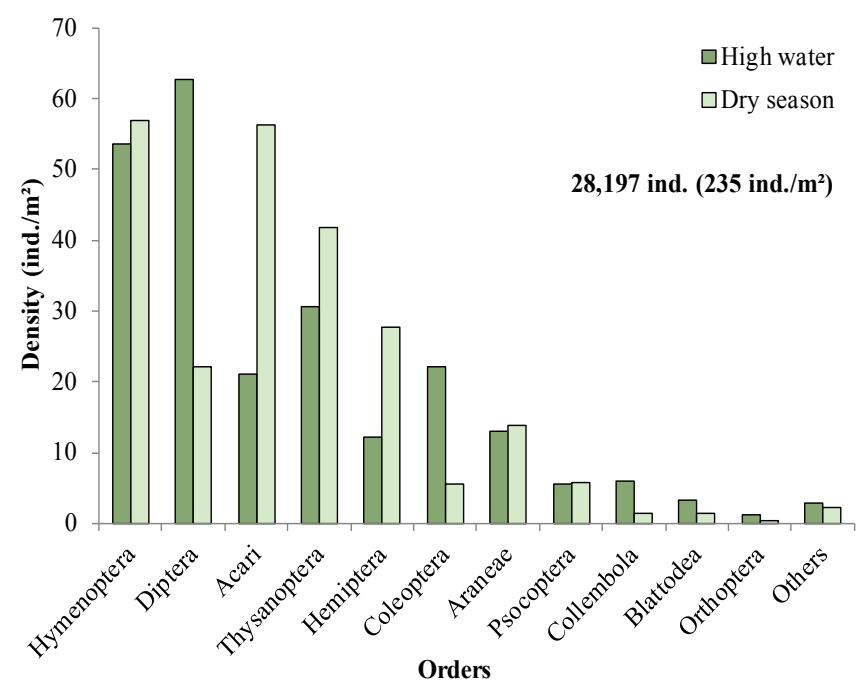

Figure 1. Comparison of arthropod density (ind. $/ \mathrm{m}^{2}$ ) in Callisthene fasciculata canopy between high water and dry season in the northern Pantanal region of Mato Grosso, Brazil.
Diplopoda individuals belonging to Polyxenida $(<0.1 \%$; 0.1 ind. $/ \mathrm{m}^{2}$ ) were collected.

Among all evaluated arthropods, only Opilions, Scorpions, Embioptera and Ephemeroptera occurred during the high water period, with Polyxenida and Strepsiptera occurring exclusively during the dry season (Table 1). The indirect ordination of the 24 sampled arthropod orders (NMDS) between the high water and dry periods resulted in a stress = 0.08 . The result of the $t$-test, which compares the axis scores, showed a difference in the distribution of arthropod orders between the two periods $(t$-test $=-8.72 ; \mathrm{df}=6.4 ; \mathrm{P}<0.01)$ (Fig. 2).

There was no significant variation in the abundance of arthropods $(t$-test $=-0.02 ; \mathrm{df}=6.8 ; \mathrm{P}=0.98)$ between the high water and dry seasons. During the high water period 14,067 arthropods were collected. Hexapoda, represented by 17 orders, was most abundant (11,963 ind.; $85.0 \%$; 199.4 ind./ $\left.\mathrm{m}^{2}\right)$. Diptera $\left(3,771\right.$ ind.; $26.8 \% ; 62.8$ ind. $\left./ \mathrm{m}^{2}\right)$, Hymenoptera $\left(3,223\right.$ ind.; $22.9 \% ; 53.7$ ind. $\left./ \mathrm{m}^{2}\right)$ and Coleoptera $(1,324$ ind.; $9.4 \% ; 22.1$ ind. $/ \mathrm{m}^{2}$ ) were the groups most represented. During high water, 2,103 Arachnida individuals (15\%; 35.1 ind. $\left./ \mathrm{m}^{2}\right)$ were sampled, distributed between Acari (1,269 ind.; $9.0 \% ; 21.1$ ind. $/ \mathrm{m}^{2}$ ) and Araneae (782 ind.; $5.6 \% ; 13.0$ ind./ $\mathrm{m}^{2}$ ), which were the most abundant taxa (Table 1; Fig. 1).

During the dry season 14,130 arthropods were sampled. Hexapoda was the most abundant class (6,313 ind.; $22.4 \%$; 51.1 ind $\left./ \mathrm{m}^{2}\right)$ with 16 orders, of which Hymenoptera $(3,412$ ind.; $24.1 \% ; 56.9$ ind. $\left./ \mathrm{m}^{2}\right)$, Thysanoptera $(2,500$ ind.; $17.7 \%$; 41.7 ind. $\left./ \mathrm{m}^{2}\right)$, Hemiptera (1,665 ind.; $11.8 \% ; 27.8$ ind. $\left./ \mathrm{m}^{2}\right)$ and Diptera (1,334 ind.; $9.4 \% ; 22.2$ ind. $\left./ \mathrm{m}^{2}\right)$ were predominant in regards to number of individuals. Acari (3,373 ind.; 23.9 $\% ; 56.2$ ind $/ \mathrm{m}^{2}$ ) and Araneae ( 828 ind.; $5.9 \% ; 13.8 \mathrm{ind} . / \mathrm{m}^{2}$ ), which were the most abundant Arachnida taxa (4,209 ind.; $29.8 \%$ and 70.1 ind. $/ \mathrm{m}^{2}$ ). Diplopoda was only found during the dry season with just 12 individuals of Polyxenida $(0.1 \%$; 0.2 ind. $/ \mathrm{m}^{2}$ ) (Table 1) being collected.

\section{Discussion and conclusion}

The arthropod community in the canopy of $C$. fasciculata was composed of 24 taxonomic orders. Of these, Hymenoptera, Diptera, Acari and Thysanoptera were the most abundant. Despite the different environmental conditions present within the Pantanal of Mato Grosso, there was no variation in abundance between high water and dry seasons, however, the distribution of these assemblage constituent taxa varied significantly between these seasonal periods. Studies on communities associated with other tree species within this same region of the Pantanal found a similar composition in terms of orders present in the assemblage, but variations between the dominant taxa when compared to $C$. fasciculata. Hymenoptera, Coleoptera and Araneae were dominant in canopies of $V$. divergens (Marques et al. 2006), and Thysanoptera was more abundant in C. brasiliense (Marques et al. 2007), while Acari dominated on Attalea phalerata (Battirola et al. 2007). However, it can be stated that orders sampled within the canopy of $C$. fasciculata correspond to the same taxa obtained in studies carried out in this same region in other plant hosts (Santos et al. 2003; Marques et al. 2001, 2006, 2007; Battirola et al. 2007). The variation in the dominant taxonomic groups could be associated with the structure, diversity of habitats and resources present on canopies of different species, like $A$. phalerata palm tree that 
Table 1. Number of individuals (N), relative abundance (\%) and density (ind. $/ \mathrm{m}^{2}$ ) of arthropods collected in Callisthene fasciculata canopy during high water and dry seasons in the northern Pantanal region of Mato Grosso, Brazil, following Rafael (2012) for taxonomic classification.

\begin{tabular}{|c|c|c|c|c|c|c|c|c|c|}
\hline \multirow[b]{2}{*}{ Taxa } & \multicolumn{3}{|c|}{ High water } & \multicolumn{3}{|c|}{ Dry season } & \multicolumn{3}{|c|}{ Total } \\
\hline & $\mathbf{N}$ & $\%$ & $\begin{array}{l}\text { Ind./m² } \\
\left(60 \mathrm{~m}^{2}\right) \\
\end{array}$ & $\mathbf{N}$ & $\%$ & $\begin{array}{l}\text { Ind./m } \mathbf{m}^{2} \\
\left(60 \mathrm{~m}^{2}\right) \\
\end{array}$ & $\mathbf{N}$ & $\%$ & $\begin{array}{c}\text { Ind./m } \mathbf{m}^{2} \\
\left(120 \mathrm{~m}^{2}\right) \\
\end{array}$ \\
\hline \multicolumn{10}{|l|}{$\underline{\text { Arachnida }}$} \\
\hline Acari & 1,269 & 9.0 & 21.1 & 3,373 & 23.9 & 56.2 & 4,642 & 16.5 & 38.7 \\
\hline Araneae & 782 & 5.6 & 13.0 & 828 & 5.9 & 13.8 & 1,610 & 5.7 & 13.4 \\
\hline Opiliones & 31 & 0.2 & 0.5 & - & - & - & 31 & 0.1 & 0.3 \\
\hline Pseudoscorpiones & 19 & 0.1 & 0.3 & 8 & 0.1 & 0.1 & 27 & 0.1 & 0.2 \\
\hline Scorpiones & 3 & $<0.1$ & $<0.1$ & - & - & - & 3 & $<0.1$ & $<0.1$ \\
\hline \multicolumn{10}{|l|}{ Diplopoda } \\
\hline Polyxenida & - & - & - & 12 & 0.1 & 0.2 & 12 & $<0.1$ & 0.1 \\
\hline \multicolumn{10}{|l|}{ Hexapoda } \\
\hline Blattodea $(A+N)^{*}$ & 196 & 1.4 & 3.3 & 88 & 0.6 & 1.5 & 284 & 1.0 & 2.4 \\
\hline Coleoptera $(\mathrm{A}+\mathrm{L})^{*}$ & 1,324 & 9.4 & 22.1 & 339 & 2.4 & 5.6 & 1,663 & 5.9 & 13.9 \\
\hline Collembola & 361 & 2.6 & 6.0 & 86 & 0.6 & 1.4 & 447 & 1.6 & 3.7 \\
\hline Dermaptera & 1 & $<0.1$ & $<0.1$ & 2 & $<0.1$ & $<0.1$ & 3 & $<0.1$ & $<0.1$ \\
\hline Diptera $(A+L)$ & 3,771 & 26.8 & 62.8 & 1,334 & 9.4 & 22.2 & 5,105 & 18.1 & 42.5 \\
\hline Embioptera & 4 & $<0.1$ & 0.1 & - & - & - & 4 & $<0.1$ & $<0.1$ \\
\hline Ephemeroptera & 32 & 0.2 & 0.5 & - & - & - & 32 & 0.1 & 0.3 \\
\hline Hemiptera & 726 & 5.2 & 12.1 & 1,665 & 11.8 & 27.8 & 2,391 & 8.5 & 19.9 \\
\hline Heteroptera $(\mathrm{A}+\mathrm{N})$ & (174) & $(24.0)$ & (2.9) & $(50)$ & $(10.0)$ & $(0.8)$ & $(224)$ & $(9.4)$ & (1.9) \\
\hline Auchenorrhyncha $(\mathrm{A}+\mathrm{N})$ & (513) & $(70.7)$ & $(8.5)$ & $(1,499)$ & $(90.0)$ & $(25.0)$ & $(2,012)$ & $(84.1)$ & $(16.8)$ \\
\hline Sternorrhyncha & (39) & $(5.4)$ & $(0.6)$ & (116) & $(0.8)$ & (1.9) & (155) & $(6.5)$ & (1.3) \\
\hline Hymenoptera & 3,223 & 22.9 & 53.7 & 3,412 & 24.1 & 56.9 & 6,635 & 23.5 & 55.3 \\
\hline Formicidae $(\mathrm{A}+\mathrm{L})$ & $(1,549)$ & $(48.1)$ & $(25.8)$ & $(1,409)$ & $(41.3)$ & $(23.5)$ & $(2,958)$ & $(44.6)$ & $(24.7)$ \\
\hline Isoptera & 2 & $<0.1$ & $<0.1$ & 5 & $<0.1$ & 0.1 & 7 & $<0.1$ & 0.1 \\
\hline Lepidoptera $(\mathrm{A}+\mathrm{L})$ & 70 & 0.5 & 1.2 & 75 & 0.5 & 1.2 & 145 & 0.5 & 1.2 \\
\hline Mantodea & 2 & $<0.1$ & $<0.1$ & 3 & $<0.1$ & $<0.1$ & 5 & $<0.1$ & $<0.1$ \\
\hline Neuroptera $(A+L)$ & 3 & $<0.1$ & $<0.1$ & 5 & $<0.1$ & $<0.1$ & 8 & $<0.1$ & 0.1 \\
\hline Orthoptera $(\mathrm{A}+\mathrm{N})$ & 73 & 0.5 & 1.2 & 24 & 0.2 & 0.4 & 97 & 0.3 & 0.8 \\
\hline Psocoptera & 335 & 2.4 & 5.6 & 347 & 2.5 & 5.8 & 682 & 2.4 & 5.7 \\
\hline Strepsiptera & - & - & - & 1 & $<0.1$ & $<0.1$ & 1 & $<0.1$ & $<0.1$ \\
\hline Thysanoptera & 1,835 & 13 & 30.6 & 2,500 & 17.7 & 41.7 & 4,335 & 15.4 & 36.1 \\
\hline Trichoptera & 5 & $<0.1$ & 0.1 & 23 & 0.2 & 0.4 & 28 & 0.1 & 0.2 \\
\hline TOTAL & 14,067 & 100.0 & 234.4 & 14,130 & 100.0 & 235.5 & 28,197 & 100.0 & 235.0 \\
\hline
\end{tabular}

*A - Adults, L - Larvae e N- Nymphs.

accumulate organic material on their leaves, used by same groups of arthropods as reproduction sites (Santos et al. 2003; Battirola et al. 2007; Marques et al. 2009, 2011).

Basset (2001) indicated that Hymenoptera, Diptera, Coleoptera, Hemiptera and Lepidoptera are among the most abundant canopy invertebrates in tropical forests. The distribution of these arthropods in tropical forests can be influenced by abiotic components, forest physiognomy type, availability of resources, as well as the specific behaviour of these invertebrates (Basset et al. 2003). For example in flood areas, flooding affects the structure of arthropod communities due to the different strategies and behaviours exhibited by these organisms during the occurrence of these adverse conditions throughout the year (Adis 1997; Adis and Junk
2002). The presence of taxa such as Scorpiones, Opiliones, Embioptera and Ephemeroptera, exclusively during the high water period, as well as Polyxenida and Strepsiptera exclusively during the dry period, shows this variation in community composition. Arthropods with generally terrestrial habits in seasonally flooded environments such as the northern Pantanal may migrate from the edaphic environment to the trunks and canopies of trees, remaining until the end of the inundation period (Adis 1997; Adis et al. 2001; Battirola et al. 2009, 2016; Wantzen et al. 2016). It was observed that Tityus paraguayensis Kraepelin, 1895 (Scorpions, Buthidae) sampled in this study used $C$. fasciculata canopy as a habitat only during the high water period, characterizing it as a refuge for this arachnid (Yamazaki et al. 2015). Thus, each plant 


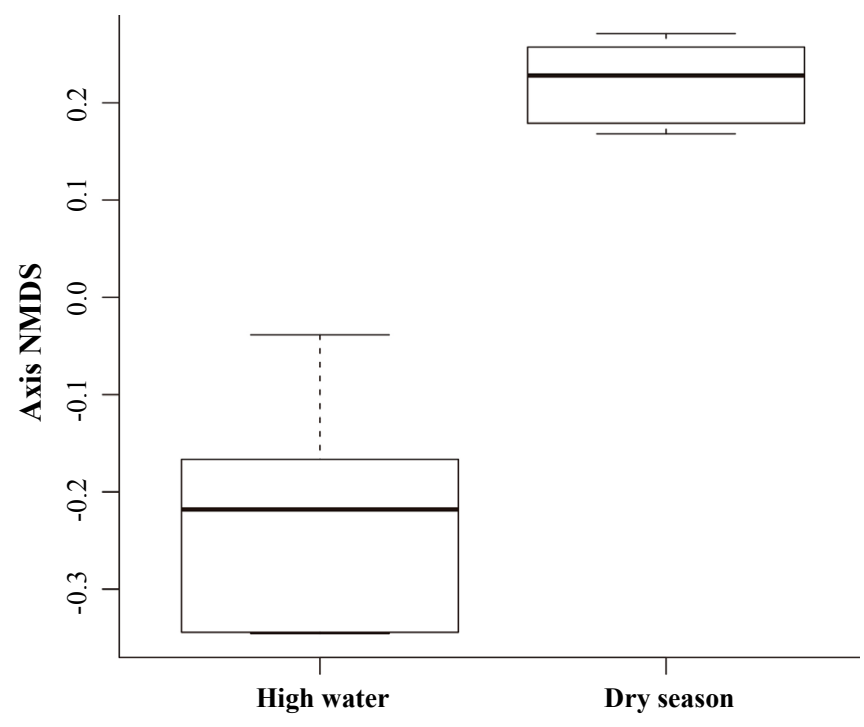

Figure 2. Comparison of NMDS axis scores, generated from the distribution of 24 arthropod orders in Callisthene fasciculata canopy between high water and dry seasons in the northern Pantanal region of Mato Grosso, Brazil.

species, habitat and region, as well as the interaction between these variables, determines distinct compositions of arthropod communities.

Diptera, Hymenoptera, Thysanoptera, Coleoptera and Acari were the most representative groups found in $C$. fasciculata during the high water period. In the Pantanal, with the exception of Thysanoptera, these taxa, or most of them, are dominant in communities associated with the canopies of other tree species (Marques et al. 2001, 2006, 2007, 2009; Battirola et al. 2007). Other groups such as Araneae (Marques et al. 2006), Collembola (Battirola et al. 2007; Marques et al. 2007) and Psocoptera (Marques et al. 2006, 2007) are also mentioned in these studies as predominant in this seasonal period. Battirola et al. (2007) have characterized the high water period as the period of higher arthropod density in $A$. phalerata canopy, with the majority of these being insects that use these habitats as a breeding site (Battirola et al. 2007; Marques et al. 2009).

Little variation was observed in relation to the dry season, apart from the exclusive sampling of Polyxenida and Strepsiptera, and the variation in abundance of some taxa. Thysanoptera was present in high abundance in both seasonal periods. However, in the dry season the number of individuals was $136.2 \%$ higher than the abundance recorded during high water. Marques et al. $(2006 ; 2007)$ also recorded Thysanoptera among the most abundant group in the dry season in the canopy of $V$. divergens and $C$. brasiliense, respectively. Basset (2001) considered Thysanoptera as a seasonal taxon, as its occurrence is often associated with the flowering of tropical trees, behaving as potential pollinators. In C. brasiliense (Marques et al. 2006) and $V$. divergens (Marques et al. 2007) the flowering period occurs during the dry season, explaining the high abundance of Thysanoptera, whereas in $C$. fasciculata the flowering occurs at the end of the dry season and the beginning of the rising water period. The distribution of many of these herbivores insects is influenced by the plant phenology (flowering, fructification, and change of foliage), as well as changes in environmental conditions (Wolda 1988).
The arthropod community in $C$. fasciculata showed no difference in abundance between the high water and dry periods, however there was greater variation between orders during high water season when compared to the dry season. The results showed similarity between the canopies of $A$. phalerata and C. fasciculata (Santos et al. 2003; Battirola et al. 2007). However, a distinct situation was recorded for $V$. divergens and $C$. brasiliense in which the abundance and diversity of arthropod groups was higher in the terrestrial phase (Marques et al. 2006, 2007). The results obtained from these studies confirm the influence of the hydrological regime in the northern Pantanal region of Mato Grosso, and also of the host plant phenology in the structuring of arthropod communities associated with different phytophysiognomies of this region. Our data indicates that the variation in distribution order between high water and dry seasons in C. fasciculata canopy can be influenced by temporal variation and probably by variation in the plant phenology. However, more in-depth studies on the relationship of seasonal hydrological variation, plant phenology and composition of the associated arthropod assemblage are needed so as to understand the dynamics present in these habitats, which are considered important in the maintenance and diversity of arthropod communities in the Brazilian Pantanal.

\section{Acknowledgements}

This study comprises part of the results of the Masters dissertation developed in the Programa de Pós-Graduação em Ciências Ambientais (UFMT/SINOP). The first author thanks to Coordenação de Aperfeiçoamento de Pessoal de Nivel Superior (CAPES), as well as to the Fundação de Amparo à Pesquisa do Estado de Mato Grosso (FAPEMAT) for financial support (FAPEMAT Process No. 737641/2008), and Núcleo de Estudos da Biodiversidade da Amazônia Matogrossense (NEBAM) for logistic support.

\section{Literature cited}

ADIS, J. 1997. Estratégias de sobrevivência de invertebrados terrestres em florestas inundáveis da Amazônia Central: Uma resposta à inundação de longo período. Acta Amazonica 27 (1): 43-54. https://doi.org/10.1590/1809-43921997271054

ADIS, J.; JUNK, W. J. 2002. Terrestrial invertebrates inhabiting lowland river floodplains of Central Amazonia and Central Europe: a review. Freshwater Biology 47 (4): 711-731. https:// doi.org/10.1046/j.1365-2427.2002.00892.x

ADIS, J.; BASSET, Y.; FLOREN, A.; HAMMOND, P. E.; LINSENMAIR, K. E. 1998. Canopy fogging of an overstory tree - recommendations for standardization. Ecotropica 4: 93-97.

ADIS, J.; MARQUES, M. I.; WANTZEN, K. M. 2001. First observations on the survival strategies of terricolous arthropods in the northern Pantanal wetland of Brazil. Andrias 15: 127128.

ADIS, J.; ERWIN, T. L.; BATTIROLA, L. D.; KETELHUT, S. M. 2010. The importance of Amazonian floodplain forests for animal biodiversity: Beetles in canopies of floodplain and upland forests. pp. 313-328. In: Junk, W. J.; Piedade, M. T. F.; Wittmann, F.; Schöngart, J.; Parolin, P. (Eds.). Amazonian floodplain forests: Ecophysiology, biodiversity and sustainable management. Ecological Studies (Analysis and Synthesis), vol 210. Springer Dordrecht. New York. 615 p. https://doi. org/10.1007/978-90-481-8725-6_16

ARIEIRA, J.; NUNES DA CUNHA $\bar{A}$, C. 2006. Fitossociologia de uma floresta inundável monodominante de Vochysia divergens 
Pohl. (Vochysiaceae), no Pantanal Norte, MT, Brasil. Acta Botanica Brasilica 20 (3): 569-580. https://doi.org/10.1590/ S0102-33062006000300007

BASSET, Y. 2001. Invertebrates in the canopy of tropical rain forests: How much do we really know? Plant Ecology 153: 87107. https://doi.org/10.1023/A:1017581406101

BASSET, Y.; HAMMOND, P. M.; BARRIOS, H.; HOLLOWAY, J. D.; MILLER, S. E. 2003. Vertical stratification of arthropod assemblages. pp. 17-27. In: Basset, Y.; Novotny, V.; Miller, S. E.; Kitching, R. L. (Eds.). Arthropods of tropical forests. Spatiotemporal dynamics and resource use in the canopy. Cambridge University Press. Cambridge, England. 474 p.

BATTIROLA, L. D.; MARQUES, M. I.; ADIS, J.; BRESCOVIT, A. D. 2004. Aspectos ecológicos da comunidade de Araneae (Arthropoda, Arachnida) em copas da palmeira Attalea phalerata Mart. (Arecaceae) no Pantanal de Poconé, Mato Grosso, Brasil. Revista Brasileira de Entomologia 48 (3): 421-430. https://doi. org/10.1590/S0085-56262004000300020

BATTIROLA, L. D.; MARQUES, M. I.; ADIS, J.; DELABIE, J. H. C. 2005. Composição da comunidade de Formicidae (Insecta, Hymenoptera) em copas de Attalea phalerata Mart. (Arecaceae) no Pantanal de Poconé, Mato Grosso, Brasil. Revista Brasileira de Entomologia 49 (1): 107-117. https://doi.org/10.1590/S008556262005000100011

BATTIROLA, L. D.; ADIS, J.; MARQUES, M. I.; SILVA, F. H. O. 2007. Comunidade de artrópodes associados à copa de Attalea phalerata Mart. (Arecaceae) durante o período de cheia no Pantanal de Poconé, MT. Neotropical Entomology 36 (5): 640651. https://doi.org/10.1590/S1519-566X2007000500002

BATTIROLA, L. D.; MARQUES, M. I.; ROSADO-NETO, G. H.; PINHEIRO, T. G.; PINHO, N. G. C. 2009. Vertical and time distribution of Diplopoda (Arthropoda: Myriapoda) in a monodominant forest in Pantanal of Mato Grosso, Brazil. Zoologia 26 (3): 479-487. https://doi.org/10.1590/S198446702009005000008

BATTIROLA, L. D.; SANTOS, G. B.; ROSADO-NETO, G. H.; MARQUES, M. I. 2014. Coleoptera (Arthropoda, Insecta) associados às copas de Attalea phalerata Mart. (Arecaceae) no Pantanal de Poconé, Mato Grosso, Brasil. EntomoBrasilis 7 (1): 20-28. https://doi.org/10.12741/ebrasilis.v7i1.316

BATTIROLA, L. D.; BATISTELLA, D. A.; ROSADO-NETO, G. H.; BRESCOVIT, A. D.; MARQUES, M. I. 2016. Spider assemblage (Arachnida: Araneae) associated with canopies of Vochysia divergens (Vochysiaceae) in the northern region of the Brazilian Pantanal. Zoologia 33 (4): e20150170.

BATTIROLA, L. D.; ROSADO-NETO, G. H.; BATISTELLA, D. A.; MAHNERT, V.; BRESCOVIT, A. D.; MARQUES, M. I. 2017a. Vertical and time distribution of Pseudoscorpiones (Arthropoda: Arachnida) in a floodplain forest in the Brazilian Pantanal. Revista de Biología Tropical 65 (2): 445-459. https:// doi.org/10.15517/RBT.V65I2.24134

BATTIROLA, L. D.; SANTOS, G. B.; MEURER, E.; CASTILHO, A. C. C.; MAHNERT, V.; BRESCOVIT, A. D.; MARQUES, M. I. 2017b. Soil and canopy Pseudoscorpiones (Arthropoda, Arachnida) in a monodominant forest of Attalea phalerata Mart. (Arecaceae) in the Brazilian Pantanal. Studies on Neotropical Fauna and Environment 52 (2): 1-8. https://doi.org/10.1080/01 650521.2017 .1282210

CORSINI, E.; GUARIM-NETO, G. 2000. Aspectos ecológicos da vegetação de "carvoal (Callisthene fasciculata (Spr.) Mart.) no Pantanal mato-grossense. pp. 1-52. In: Anais do III Simpósio sobre recursos naturais e socioeconômicos do Pantanal. Embrapa/UFMS. Corumbá, Brazil. 463 p.

CUSTÓDIO, L. N.; CARMO-OLIVEIRA, R.; MENDESRODRIGUES, C.; OLIVEIRA, P. E. 2014. Pre-dispersal seed predation and abortion in species of Callisthene and Qualea (Vochysiaceae) in a Neotropical savanna. Acta Botanica Brasilica 28 (3): 309-320. https://doi.org/10.1590/0102$33062014 \mathrm{abb} 3064$
HASENACK, H.; CORDEIRO, J. L. P.; HOFMANN, G. S. 2003. O clima da RPPN Sesc Pantanal. UFRGS, Porto Alegre, Brazil. $31 \mathrm{p}$.

HECKMAN, C. W. 1998. The Pantanal of Poconé. Biota and ecology in the northern section of the world's largest pristine wetland. Kluwer Academic Publishers, Dordrecht, Netherlands. 624 p.

JUNK, W. J. 1993. Wetlands of tropical South America. pp. 679-739. In: Whigham, D. F.; Hejný, S.; Dykyjová, D. (Eds.). Wetlands of the world: Inventory, ecology and management. Vol. 1. Handbook of vegetation science. Springer, Dordrecht, Netherlands. 768 p. https://doi.org/10.1007/978-94-015-8212-4 14

JUNK, W. J.; NUNES-DA-CUNHA, C.; WANTZEN, K. M.; PETERMANN, P.; STRÜSSMANN, C.; MARQUES, M. I.; ADIS, J. 2006. Biodiversity and its conservation in the Pantanal of Mato Grosso, Brazil. Aquatic Sciences 68 (3): 278-309. https://doi.org/10.1007/s00027-006-0851-4

JUNK, W. J.; PIEDADE, M. T. F.; LOURIVAL, R.; WITTMANN, F.; KANDUS, P.; LACERDA, L. D.; BOZELLI, R. L.; ESTEVES, F. A.; NUNES-DA-CUNHA, C.; MALTCHIK, L.; SCHÖNGART, J.; SCHAEFFER-NOVELLI, Y.; AGOSTINHO, A. A.; NOBREGA, R. L. B.; CAMARGO, E. 2015. Classificação e delineamento das áreas úmidas brasileiras e de seus macrohabitats. pp. 13-76. In: Nunes-da-Cunha, C.; Piedade, M. T. F.; Junk, W. J. (Eds.). Definição e classificação das áreas úmidas (AUs) brasileiras, base científica para uma nova política de proteção e manejo sustentável. INCT-INAU - EdUFMT. Cuiabá, Brazil. 67 p.

MARQUES, M. I.; ADIS, J.; NUNES-DA-CUNHA, C.; SANTOS, G. B. 2001. Arthropod biodiversity in the canopy of Vochysia divergens Pohl (Vochysiaceae), a forest dominant in the Brazilian Pantanal. Studies on Neotropical Fauna and Environment 36 (3): 205-210. https://doi.org/10.1076/snfe.36.3.205.2122

MARQUES, M. I.; ADIS, J.; SANTOS, G. B.; BATTIROLA, L. D. 2006. Terrestrial arthropods from tree canopies in the Pantanal of Mato Grosso, Brazil. Revista Brasileira de Entomologia 50 (2): 257-267. https://doi.org/10.1590/S0085-56262006000200007

MARQUES, M. I.; ADIS, J.; BATTIROLA, L. D.; BRESCOVIT, A. D.; SILVA, F. H. O.; SILVA, J. L. 2007. Composição da comunidade de artrópodes associada à copa de Calophyllum brasiliense Cambess. (Guttiferae) no Pantanal mato-grossense, Mato Grosso, Brasil. Amazoniana 19 (3/4): 131-148.

MARQUES, M. I.; SANTOS, G. B.; BATTIROLA, L. D.; TISSIANI, A. S. O. 2009. Entomofauna associada à matéria orgânica em bainhas foliares de Attalea phalerata Mart. (Arecaceae), na região norte do Pantanal de Mato Grosso. Acta Biológica Paranaense 38 (3-4): 93-112. https://doi.org/10.5380/ abpr.v38i0.16418

MARQUES, M. I.; ADIS, J.; BATTIROLA, L. D.; SANTOS, G. B.; CASTILHO, A. C. C. 2011. Arthropods associated with a forest of Attalea phalerata Mart. (Arecaceae) palm trees in the northern Pantanal of the Brazilian state of Mato Grosso. pp. 431-468. In: Junk, W. J.; Da-Silva, C. J.; Nunes-da-Cunha, C.; Wantzen, K. M. (Eds.). The Pantanal: ecology, biodiversity and sustainable management of a large neotropical seasonal wetland. Pensoft Publishers. Sofia-Moscow. 870 p.

MARQUES, M. I.; SANTOS, G. B.; BATTIROLA, L. D. 2014. Cerambycidae (Insecta, Coleoptera) associados à Vochysia divergens Pohl (Vochysiaceae) na região norte do Pantanal de Mato Grosso, Brasil. EntomoBrasilis 7 (2): 159-160. https://doi. org/10.12741/ebrasilis.v7i2.317

MOFFETT, M. W. 2000. What's "Up"? A critical look at the basic terms of canopy biology. Biotropica 32 (4a): 569-596. https:// doi.org/10.1646/0006-3606(2000)032[0569:WSUACL]2.0. $\mathrm{CO} ; 2$

NADKARNI, N. M. 1994. Diversity of species and interactions in the upper tree canopy of forest ecosystems. American Zoologist 34 (1): 70-78. https://doi.org/10.1093/icb/34.1.70

NUNES-DA-CUNHA, C.; JUNK, W. J. 2011. A preliminary classification of habitats of the Pantanal of Mato Grosso and 
Mato Grosso do Sul, and its relation to national and international wetland classification systems. pp. 127-141. In: Junk, W. J.; Silva, C. J.; Nunes-da-Cunha, C.; Wantzen, K. M. (Eds.). The Pantanal, Ecology, biodiversity and sustainable management of a large Neotropical seasonal wetland. Pensoft, Sofia, Moscow. $870 \mathrm{p}$.

NUNES-DA-CUNHA, C.; JUNK, W. J. 2015. A classificação dos macrohabitats do Pantanal Matogrossense. pp. 77-122. In: Nunes-da-Cunha, C. Piedade, M. T. F.; Junk, W. J. (Eds.). Classificação e delineamento das áreas úmidas brasileiras, e de seus macrohabitats. EdUFMT, Cuiabá, Brazil. 165 p.

OKSANEN, J.; BLANCHET, F. G.; KINDT, R.; LEGENDRE, P.; MINCHIN, P. R.; O'HARA, R. B.; SIMPSON, G. L.; SOLYMOS, M. P.; STEVENS, H. H.; WAGNER, H. 2013. Vegan: Community Ecology. Package. R package version 2.08. http://CRAN.R-project.org/package=vegan. [Review date: 16 November 2014].

POTT, A.; POTT, V. J. 1994. Plantas do Pantanal. Embrapa-SPI, Corumbá, Brazil. 320 p.

R CORE TEAM. 2013. R: A language and environment for statistical computing. R Foundation for Statistical Computing, Vienna, Austria. http://www.R-project.org/. [Review date: 16 November 2014].

RADAMBRASIL. 1982. Departamento de Produção Mineral. Levantamento de Recursos Naturais. Folha (SD-21) Cuiabá. Projeto Radambrasil, Rio de Janeiro, Brazil. 554 p.

RAFAEL, J. A. 2012. Chave para as ordens - adultos. pp. 192-196. In: Rafael, J. A.; Melo, G. A. R.; Carvalho, C. J. B.; Casari, S. A.; Constantino, R. (Eds.). Insetos do Brasil - diversidade e taxonomia. Holos Editora. Ribeirão Preto, Brazil. 810 p.

SANTOS, G. B.; MARQUES, M. I.; ADIS, J.; MUSIS, C. R. 2003. Artrópodos associados à copa de Attalea phalerata Mart. (Arecaceae), na região do Pantanal de Poconé, Mato Grosso, Brasil. Revista Brasileira de Entomologia 47 (2): 211-224. https://doi.org/10.1590/S0085-56262003000200010

WANTZEN, K. M.; MARCHESE, M. R.; MARQUES, M. I.; BATTIROLA, L. D. 2016. Invertebrates in neotropical floodplains. pp. 493-524. In: Batzer, D.; Boix, D. (Eds.). Invertebrates in freshwater wetlands. Springer International Publishing. Switzerland. 645 p. https://doi.org/10.1007/978-3319-24978-0_14
WOLDA, H. 1988. Insect seasonality: Why? Annual Review of Ecology and Systematics 19: 1-18. https://doi.org/10.1146/ annurev.es.19.110188.000245

YAMAZAKI, L.; MARQUES, M. I.; BRESCOVIT, A. D.; BATTIROLA, L. D. 2015. Tityus paraguayensis (Scorpiones: Buthidae) em copas de Callisthene fasciculata (Vochysiaceae) no Pantanal de Mato Grosso (Brasil). Acta Biológica Paranaense 44 (3-4): 153-158.

YAMAZAKI, L.; DAMBROZ, J.; MEURER, E.; VINDICA, V. F.; DELABIE, J. H. C.; MARQUES, M. I.; BATTIROLA, L. D. 2016. Ant community (Hymenoptera: Formicidae) associated with Callisthene fasciculata (Spr.) Mart. (Vochysiaceae) canopies in the Pantanal of Poconé, Mato Grosso, Brazil. Sociobiology 63 (2): 735-743. http://dx.doi.org/10.13102/sociobiology.v63i2.824

YAMAZAKI, L.; VINDICA, V.F.; BRESCOVIT, A. D.; MARQUES, M. I.; BATTIROLA, L. D. 2017. Temporal variation in the spider assemblage (Arachnida, Araneae) in canopies of Callisthene fasciculata (Vochysiaceae) in the Brazilian Pantanal biome. Iheringia Série Zoologia 107: e2017019. https://doi. org/10.1590/1678-4766e2017019

\section{Origin and funding}

This study was funded by Fundação de Amparo à Pesquisa do Estado de Mato Grosso (FAPEMAT - Process No. 737641/2008).

\section{Author contribution}

Lúcia Yamazaki: carried out experimental design, insect collections, lab experiments, statistical analyses and wrote the manuscript.

Vanessa França Vindica: carried out statistical analyses and wrote the manuscript.

Marinêz Isaac Marques: carried out experimental design, insect collections, lab experiments, statistical analyses and wrote the manuscript.

Leandro Dênis Battirola: carried out experimental design, insect collections, lab experiments, statistical analyses and wrote the manuscript. 